\title{
Cities of Resilience: Integrated Adaptive Planning
}

\author{
DOI: 10.12776/QIP.V21I1.776
}

\author{
Oto Hudec
}

\begin{abstract}
Purpose: to classify the definitions and approaches towards the concept of the city of resilience, to understand the reciprocal influences of academic research, resilience assessments and planning results as well as to identify the inconsistencies and formulate future research directions.
\end{abstract}

Methodology/Approach: explanatory analysis, literature-based work comparing definitions, principles, dimensions. Rationalised analytic reasoning and approaches which lead to formulating crucial research questions.

Findings: the definitions of city resilience are classified according to objects and fields. The differentiations in the sustainability and resilience concepts are indicated and an adaptive planning framework is described.

Research Limitation/implication: the main challenges are filling in the gap between the theory and practice of city resilience literature, dealing with the complexity, the implementation of complexity theory considering selforganisation.

Originality/Value of paper: the analysis contributes to the clarification of the main concept, classification of the main approaches and the formulation of open research questions and future trends.

Category: Research paper

Keywords: city of resilience; smart city; sustainable development; vulnerability; integrated planning

\section{INTRODUCTION}

Commonly recognisable qualities of resilient people are their inner strength, strong physical constitution, ability to leap back from failure and permanent 
striving for self-improvement. The same features could almost be assigned to resilient cities through their ability to last, capacity to respond to shocks or crises (Newman, et al., 2009) and their goal of becoming more co-ordinated and integrated. The best cities of such kind are not only able to adapt to shocks, but also able to discover new opportunities and perform even better in spite of perplexing circumstances. In other words, individuals and/or cities at a time of disruption should avoid panicked responses and making decisions based only on short-term considerations. Rather, long-term planning, coordination and cooperation would be the preferable reaction and in terms of adaptive resilience, the reframing of possible threats as opportunities and a change of routine practice instead.

Resilience is a relatively new term used in urban planning discussions, academic research and practice. This has been especially due to the increasing attention paid to extreme and catastrophic events and their consequences (climate change, hurricanes, terrorist attacks, earthquakes, fires, oil spills, cybercrime, epidemics as well as economic crises). Urban agglomerations and areas exhibit a high concentration of populations, physical resources, industry and technology facilities, which all mean higher vulnerability and a risk of massive catastrophic losses.

In response to concerns about the increased risk of hazards and the high discernment of the population and institutions, the focus of researchers, decision makers and practitioners has led to the design of a new concept of resilient cities. The concept deals in general with a city's ability to anticipate and mitigate hazards, its minimisation of economic and social disruption and its capacity to enhance its adaptive capacity in the case of a crisis event. The city, which belongs to a broad category of complex and adaptive socio-ecological systems (Batty, 2008; Reggiani and Nijkamp, 2009), may build significantly on the resilience theory, which was developed earlier in the fields of biology, ecology and psychology (Perrings, 1998; Pimm, 1984). Resilience theory is embedded in complexity theory, which considers self-organisation as its over-riding organising principle (Folke, 2006; Batty, 2008).

Decision makers quickly adopt attractive new research concepts (e.g. the European Commission broadly uses the words "sustainable", "resilient" or "smart" even if their content is far from being clear or there is widespread misunderstanding or deformations of the meanings). The popular smart city concept is mostly used in relation to the use of digital technologies in everyday city life, building innovative energy and transportation systems and providing efficient services to citizens. These cities are those regarded to have developed innovative, green, environmentally friendly energy and water solutions as well as the use of integrated mobility systems to achieve secure mobility. In this way, the smart approaches can be recognised as a tool which possibly strengthens the resilience of a city and contributes to local or even global sustainability. 
In comparison to the smart city concept, the resilience attribute is assigned to cities which are supposed to be able to cope with external shocks and hazards, demonstrating their high adaptive capacity. However, the concepts of smart and resilient cities have not yet been agreed on sufficiently. There are ambiguities in their definitions as well as concerns with regard to the applicability of resilience and smartness as theoretical constructs. There is still the need to find a reasonable content for the rather broad and blurred definition of resilience, to operationalize it and to find an evolutionary approach which can address the weaknesses in urban planning. Perhaps the move will go in the opposite direction. The positive experience of more than a few cities in supporting their resistance to external shocks and increase of their adaptive capacity will help to define city resilience more properly. More than clear is the understanding of the complexity of urban systems as organic ones (Jacobs, 1961), calling for the development of appropriate and interrelated sub-categories of the multidimensional concept as well as integrated procedures which would put together land and strategic planning, risk management, intelligent resource management, technological expertise, digital solutions and social science. This may only be the case if community resilience and adaptive capacity are stimulated and boosted by integrating human, social and economic capital.

\section{INTERDISCIPLINARY APPROACHES TO RESILIENCE}

Persons, populations or cities can be harmed by external shocks and can even die or disappear in the worst case scenario. The seminal paper on the behaviour of ecological systems (Holling, 1973) not only deals with their stability (the maintenance of a predictable world) but also with resilience (the need for persistence, the qualitative capacity to absorb and accommodate unexpected future events). In psychiatry/psychology, resilience refers to adaptation within the context of significant adversity; the positive adaptation of an individual is studied after exposure to a significant threat (Garmezy, 1991). In light of the resilience theory, the city as an urban system copes with exogenous disturbances.

In the beginning, research on city resilience focused on the bounce back from a crisis to the previous state or path (exact meaning of the Latin term resilio). However, the speed of recovery and the return to equilibrium are more typical for physical and engineering sciences and such a meaning refers to engineering resilience, as the time needed to return to a global equilibrium following a disturbance (Pimm, 1984). For ecosystems, including cities, another ecological definition of resilience should be applied (Holling, 1973). This has been described as the ability/capacity of a city to absorb disturbance while maintaining its functions, structure, identity and feedback (Lu and Stead, 2013; Walker and Salt, 2006). This definition can be taken forward another step where adaptive resilience considers positive structural and qualitative change, replacing 'bounce back' by 'bounce forward' (Folke, 2006; Simmie and Martin, 2010). Resilience is in that way shifted to evolutionary resilience and the new aspect of the 
reasoning is transformation. However, this creates a serious ambiguity in the meaning of resilience, comprising both of "change" and "resistance to change" (Olsson, Galaz and Boonstra, 2014).

In the field of urban design, business and disaster management, another approach to resilience is advocated, which highlights readiness. This is referred to as anticipatory adaptability. The infrastructure designer should always take into account the future growth of a city, in order to add to the design the anticipatory adaptability to the risk of disasters and disorders. A disaster resilient city is able to reduce future hazards and its susceptibility to them. However, these functioning mechanisms and structures are predominantly built within the meaning of engineering resilience, as preparedness for prevention and adequate responses and recovery to expected or unexpected disasters and shocks (Wamsler, Brink and Rivera, 2013).

An impressive range of approaches to resilience shows its immense complexity and multi-disciplinarity. Therefore, numerous possible definitions and explanations of resilience exist. The object of study can be highly dissimilar (material, individuals, cities, ecological systems, etc.) as well as the field of study (material science, psychology, social ecology, economics, etc.), using object/field specific definitions of resilience. Thus, only a rather broad and flexible definition can serve as a denominator to very different meanings justifying particular interests and goals. Indeed, perhaps the goal should not be to unify all the approaches and to create a single theory - pluralism is an alternative, if no unified theories are available to explain a phenomenon (Olsson, et al., 2015). The following table (Tab. 1) provides a classification of both original and novel approaches. It also highlights economic resilience which has been discussed intensively due to the financial crisis 2007-2008 (Briguglio, 2009; Hassink, 2010; Lagravinese, 2015; Martin and Sunley, 2015; Modica and Reggiani, 2015).

Table 1 - Resilience types, objects and fields of study

\begin{tabular}{|l|l|l|}
\hline $\begin{array}{l}\text { Definition/ } \\
\text { Type }\end{array}$ & Object and main fields of use & Sources \\
\hline $\begin{array}{l}\text { Engineering } \\
\text { resilience }\end{array}$ & $\begin{array}{l}\text { Object: material, physical system, network, economy. } \\
\text { Fields: physics, material science, engineering (elastic } \\
\text { range in which a system can be perturbed or deformed } \\
\text { without losing the ability to return to its original } \\
\text { form), computer science (network resilience), } \\
\text { psychology, medicine (bounce back from adversity), } \\
\text { international relations (security and critical } \\
\text { infrastructure) } \\
\text { Economic resilience (to recover from the shock). }\end{array}$ & $\begin{array}{l}\text { Palker, et al., 2006; } \\
\text { Briguglio, 2009; } \\
\text { Simmie and Martin, 2010. }\end{array}$ \\
\hline $\begin{array}{l}\text { Ecological } \\
\text { resilience }\end{array}$ & $\begin{array}{l}\text { Object: individuals, families, communities, socio- } \\
\text { ecological systems, ecosystems, cities. } \\
\text { Fields: ecology, environmental sciences, biology, } \\
\text { social ecology (the level of disturbance that an } \\
\text { ecosystem can absorb without crossing a threshold to }\end{array}$ & $\begin{array}{l}\text { Holling, 1973; } \\
\text { Gunderson and Holling, } \\
\text { 2002; } \\
\text { Martin, 2012; } \\
\text { Modica and Reggiani, 2015. }\end{array}$ \\
\hline
\end{tabular}




\begin{tabular}{|c|c|c|}
\hline Definition/ & Object and main fields of use & Sources \\
\hline & $\begin{array}{l}\text { a different ecosystem structure or state), psychology } \\
\text { (positive adaptation). } \\
\text { Economic resilience (shock has the power to change } \\
\text { economic structures, and the return to pre-shock state } \\
\text { or path is impossible - hysteresis). }\end{array}$ & \\
\hline $\begin{array}{l}\text { Adaptive or } \\
\text { evolutionary } \\
\text { resilience }\end{array}$ & $\begin{array}{l}\text { Object: individuals, societal systems, cities. } \\
\text { Fields: psychological sciences, organisational theory; } \\
\text { capacity to undergo a successful change in structures, } \\
\text { functions and behaviour. } \\
\text { Economic resilience (shocks as 'gales' of creative } \\
\text { destruction and 'competitive selection). Links to } \\
\text { evolutionary economics and complex adaptive } \\
\text { systems theory (modularity and redundancy). }\end{array}$ & $\begin{array}{l}\text { Luthar, Cicchetti and Becker, } \\
\text { 2000; } \\
\text { Pelling, 2011; } \\
\text { Davoudi, et al., 2012; } \\
\text { Martin and Sunley, } 2015 .\end{array}$ \\
\hline $\begin{array}{l}\text { Anticipatory } \\
\text { adaptability }\end{array}$ & $\begin{array}{l}\text { Object: individuals, firms, societal systems, cities. } \\
\text { Fields: urban design, business studies, disaster } \\
\text { management. } \\
\text { Economic resilience: (to prevent the impacts by } \\
\text { creating resilient economic structure). }\end{array}$ & $\begin{array}{l}\text { Hamel and Välikangas, } \\
2003 ; \\
\text { Norris, et al., 2008; } \\
\text { Martin and Sunley, 2015; } \\
\text { Mykhnenko, 2016. }\end{array}$ \\
\hline
\end{tabular}

The classification of the rather different views on resilience does not provide a basis for formulating a unified approach to measuring, assessing and promoting resilience as a key setting in strategic decision-making. This makes it all the more important to raise questions to clarify the relationship between resilience, sustainability and smartness and to interconnect the rich academic discussion with the parallel practice of policy-making.

\section{RESEARCH QUESTIONS AND METHODS}

The city of resilience, the resilient city or urban resilience are evolving constructs which need to be examined in the light of different fields of research (engineering, ecological, adaptive systems, urban planning, risk management, etc.) At the same time, it makes sense to find the position of resilience in relation to smart and sustainable city strategies. Hence, a literature-based work comparing definitions, principles, dimensions and approaches is firstly needed with the aim of defining reasonable research questions:

- What is the difference between sustainability and resilience?

- Are smart cities also resilient? What is the difference between smart, resilient and sustainable cities?

- Which definition of the city of resilience is the most suitable and in accordance with the methods of assessment and operationalization?

- How can the adaptive planning framework be described? 
The literature research has identified the most influential studies and is used to compare the meaning of the concept across different disciplines. This serves as a basis for exploratory comparative analysis of the theory with the methods of assessment of a city's resilience (Resilient cities: a Grosvenor research report, and 100 resilient cities: Rockefeller Foundation). A shorter comparative analysis is also used to find and explain the similarities and differences between the theoretical basis, assessment methods and variables and practical experience. This makes it possible to foster a debate on the inconsistencies in the general resilience framework and to provide grounds for advocating co-ordinated and integrated approaches to planning and decision-making.

\section{EVOLUTION OF ENVIRONMENTAL CONCEPTS OF SOCIO- ECOLOGICAL SYSTEMS}

As with all new buzzwords, there is the natural question of which issue is being addressed or whether it is merely old content explained with different language to impress the audience. The concept of resilience is imported to urban theory from other fields such as ecology, physics and psychology. Yet, its meaning and application differs due to the object of study - the city as a complex societal system - being rather different. A mechanical application of the concept is hardly possible which subsequently generates a discussion on its proper meaning.

Metaphorically said - is resilience only a new word for the depleted term of sustainability? Before resilience, sustainability was the most related environmental mantra which was massively used. Over the years, efforts have moved from the first static approaches of environment protection to more systemic sustainability planning and more recently to resilience which also reflects dynamics. As inspired by Stumpp (2013) and Folke (2006), the development of the notions is explained in Tab. 2, differentiating roots and methodological insights:

Table 2 - Evolution of environmental concepts of socio-ecological systems

\begin{tabular}{|l|l|l|}
\hline $\begin{array}{l}\text { Local Environment } \\
\text { protection (1890 - ) }\end{array}$ & Sustainability (1970 - ) & Resilience (1990 -) \\
\hline $\begin{array}{l}\text { Roots: response to } \\
\text { smoke pollution during } \\
\text { the Industrial Revolution. }\end{array}$ & $\begin{array}{l}\text { Roots: energy crises 1973 and } \\
\text { 1979, recognition of the } \\
\text { dependence on non-renewable } \\
\text { resources }\end{array}$ & $\begin{array}{l}\text { Roots: disaster risk management } \\
\text { and climate change }\end{array}$ \\
\hline $\begin{array}{l}\text { Insight: static } \\
\begin{array}{l}\text { Approach: protection } \\
\text { meffects of human activity on } \\
\text { the natural environment. }\end{array}\end{array}$ & $\begin{array}{l}\text { Approach: the growth of long- } \\
\text { term consumption is systemic, } \\
\text { linear (endurance of systems and } \\
\text { processes not depleting natural } \\
\text { resources) or circular (producing } \\
\text { no waste and pollution). }\end{array}$ & $\begin{array}{l}\text { Approach: attributes of complex } \\
\text { adaptive system theory, panarchy } \\
\text { as a hierarchical system with } \\
\text { multiple interrelated self- } \\
\text { organising elements, } \\
\text { transformability as a capacity to } \\
\text { create fundamentally new } \\
\text { development trajectories. }\end{array}$ \\
\hline
\end{tabular}


Both sustainability and resilience are extensively used although unfortunately both have numerous interpretations and are hardly measurable. Resilience thinking is clearly close to the sustainability paradigm, pointing out the need for persistence, focusing on maintaining prosperous socio-ecological systems and sharing the system thinking. However, there is a substantial difference between the two terms. Sustainability is understood as a set of protection goals to maintain different forms of capital for future generations. In other words, to preserve and protect. It often fails at the process level if there is a need to adapt to current and future shocks or challenges. The complex dynamics also require adaptation and a set of approaches and procedures to cope with unpredictable change. The resilience of a city can therefore be understood as a single concept as well as an extension of the previous approach of sustainable urban development.

A rather different is the result of comparisons with the expansion of the smart city initiatives across the world, following the "urban labelling" phenomenon (Hollands, 2008). A well-chosen integrative metaphor can become an effective tool for the creation and implementation of innovative ideas (Pickett, Cadenasso and Grove, 2004). However, a shift from the original meaning of smart city (Caragliu, Del Bo and Nijkamp, 2011) as a strategic device for integrating modern urban production factors to the city branding field has made the concept fuzzier.

Miscellaneous assessment tools of urban sustainability, resilience and smartness focus on different domains, which can be common or different. The variables assigned to domains vary as well and their use is limited to the availability of data. To some extent, the composite indices in use address the same or similar issues. A distinctive aspect of smart cities is the use of modern technologies and the main fields of interest are energy, transport and ICT. Conversely, a comparison of the most important assessment systems confirms a greater emphasis of sustainability and resilience framework on the natural and built environment, water and waste management and energy (Ahvenniemi, et al., 2017). The assessment frameworks are not complementary, but a consensus exists only in the importance of the domain of well-being, health and safety. Smart assessment indicators cover, to a much larger extent, the economic and social aspects of a city.

\section{EVALUATION AND PLANNING}

The conceptual problem of resilience is discussed in a number of articles resulting in ambiguous conclusions and opinions all looking for the best possible definitions (Batty, 2008; Godschalk, 2003; Meerow, Newell and Stults, 2016; Newman, et al., 2009; Papa, et al., 2015; Pendall, et al., 2010). On the other hand, decision makers and practitioners have already started to design and implement resilient strategies in the context of local hazards and adaptation to climate change in light of their previous negative experience with earthquakes, 
floods, tsunamis and drought (Rogers, et al., 2012). Successful attempts to evaluate city resilience have been undertaken in order to identify reasonable benchmarks and variables for cities and to share knowledge of best practices globally. Several influential civil society organisations have already declared their involvement in a resilience movement and started to finance and measure city resilience (Resilient cities: a Grosvenor research report and 100 resilient cities: Rockefeller Foundation). It is of interest to study how their approach relates to resilience theory definitions (Tab. 3).

Table 3 - Basis, qualities, approach and visions in city resilience evaluation

\begin{tabular}{|c|c|c|c|}
\hline Organisation & Definition & $\begin{array}{l}\text { Dimensions - qualities of } \\
\text { resilience systems }\end{array}$ & Approach and vision \\
\hline Grosvenor & $\begin{array}{l}\text { Engineering } \\
\text { resilience: the ability } \\
\text { of a city to avoid or } \\
\text { bounce back from an } \\
\text { adverse event. Focus } \\
\text { on vulnerability and } \\
\text { adaptive capacity. }\end{array}$ & $\begin{array}{l}\text { Resilient Cities Research } \\
\text { Report: } \\
\text { Vulnerability: climate, } \\
\text { environment, resource, } \\
\text { infrastructure, community; } \\
\text { Adaptive capacity: } \\
\text { governance, institutions, } \\
\text { technical and learning, } \\
\text { planning systems, funding } \\
\text { structures. }\end{array}$ & $\begin{array}{l}\text { Model - two indices of } \\
\text { vulnerability and adaptive } \\
\text { capacity; } \\
\text { Vision: long-term stability and } \\
\text { prosperity of cities, real } \\
\text { estate business; } \\
\text { Novel aspects: rates of } \\
\text { population growth and impact } \\
\text { on property pricing. }\end{array}$ \\
\hline $\begin{array}{l}\text { Rockefeller } \\
\text { Foundation }\end{array}$ & $\begin{array}{l}\text { Engineering and } \\
\text { ecological resilience } \\
\text { combination: the } \\
\text { ability to recover } \\
\text { quickly and } \\
\text { effectively, ability to } \\
\text { withstand shocks } \\
\text { while still } \\
\text { maintaining its } \\
\text { essential functions. }\end{array}$ & $\begin{array}{l}\text { City Resilience Index } \\
\text { 1. Reflective } \\
\text { 2. Robust } \\
\text { 3. Redundant } \\
\text { 4. Flexible } \\
\text { 5. Resourceful } \\
\text { 6. Inclusive } \\
\text { 7. Integrated }\end{array}$ & $\begin{array}{l}\text { Model - composite index - } \\
\text { based on the analysis of the } \\
\text { factors of resilience from many } \\
\text { sources - literature, case } \\
\text { studies, and cities. Joint } \\
\text { learning of networked resilient } \\
\text { cities; } \\
\text { Vision: holistic cross-sectoral } \\
\text { city; } \\
\text { Novel aspects: } \\
\text { urban planning and strategy, } \\
\text { leadership and coordination. }\end{array}$ \\
\hline
\end{tabular}

Planning of resilience can be considered as improving the situation in the dimensions described in both indices. There are several respected models, e.g. Resilience Inference Measurement (Dept. of Environmental Sciences, Louisiana State University) (Fig. 1) which serves as a basis for the implementation of adaptive planning. 


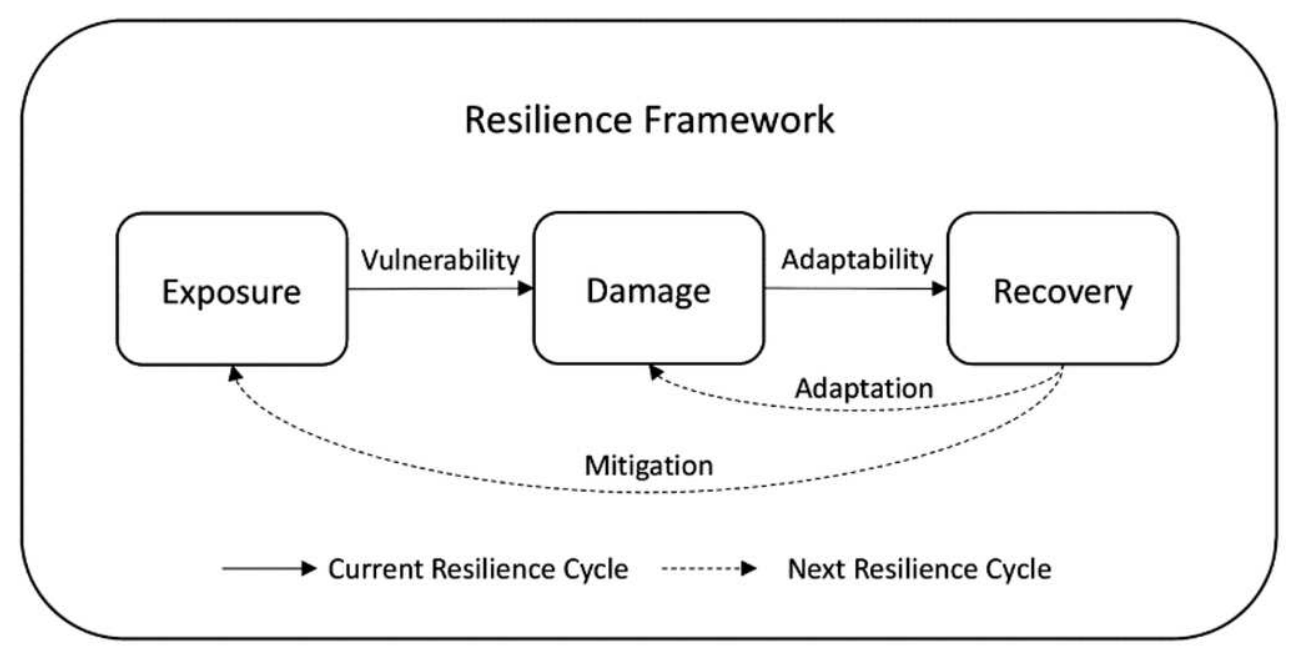

Figure 1 - Resilience Inference Measurement

However, there is still a gap between the theoretical ideas and what is done in cities. Recently, a conceptual framework for the resilient city and resilient community has been published (Jabareen, 2013). This attempts to fill in the gap between the theory and practice of city resilience literature whilst taking into account both the complexity and uncertainty.

\section{CONCLUSION}

The article has raised some open-ended questions in relation to resilience. The differentiation between the concepts of resilience and sustainability is only formulated from the viewpoint of linearity and dynamics. A more detailed distinction between the two notions is far from reaching the state of boundaries between two compact theories. However, there is a significant difference between resilience and sustainability on one side and smartness on the other. The framework of a smart city in the assessment models ensures greater concentration on the economic and social aspects, which highlights resilience as dealing more with the natural and built environment instead.

The efforts to build a single theory of resilience remain frozen in the current stage of development also due to the differences between the disciplines. Academic research does not yet provide appropriate methods of assessment and operationalization. Nevertheless, the approach is already anchored in urban planning based on past experience with the adverse impacts of climate change, hurricanes, terrorist attacks, earthquakes, epidemics and economic crises.

Peter Hall has highlighted the culture of improvement found in the heart of a city's culture as "the desire to experiment and innovate" explaining why some cities adapt more rapidly than others. The ability to recognise and evaluate culture and informal institutions remains one of the challenges also for cities. 
The initiatives of civil society organisations, city planners and many resilient cities have moved forward the concept of resilience instead of sustainability. However, this is certainly not a minor task and the cost of resilience is high. Cities are networked, complex urban systems comprising of dynamic relationships between physical and social networks. As such, urban systems represent accumulation and congestion of physical, ecological, technical and social components. This implies a challenge for urban resilience planning; how to deal with the complexity, how to implement complexity theory models considering self-organisation as a principle as well as how to intensify the collaboration of experts from all fields and to enforce an integrated approach among, so far, only formally cooperating parties.

The adaptive planning framework can be described, operationalized and implemented by the decision makers and planners even without achieving a consensus in the theoretical and empirical literature. Since Hurricane Katrina in 2005 which devastated Gulf Coast cities and the Indian Ocean tsunami of 2004, efforts to identify hazards and to assess exposure and vulnerability have brought many positive examples of effective policy strategies, subsequently building the resilience of cities.

Nonetheless, a rather open research space still exists in the study of the factors of economic resilience (structural diversity, modularity, redundancy, selforganization, criticality) as well as what kind of economic structure can positively influence the city exposure and vulnerability to numerous types of future shocks (Martin and Sunley, 2015).

\section{ACKNOWLEDGMENTS}

This work was supported by the project of Ministry of Education of the Slovak Republic: VEGA-1/0454/15 "Redefining regional development - moving towards resilient regions" and by the project of the Slovak Research and Development Agency APVV-14-0512 "Universities and economic development of regions UNIREG".

\section{REFERENCES}

Ahvenniemi H., Huovila A., Pinto-Seppä, I. and Airaksinen, M., 2017. What are the differences between sustainable and smart cities?. Cities, 60(Part A), pp.234245.

Batty, M., 2008. The size, scale, and shape of cities. Science, [e-journal] 319(5864), pp.769 - 771. http://dx.doi.org/10.1126/science.1151419.

Briguglio, L., Cordina, G., Farrugia N. and Vella, S., 2009. Economic vulnerability and resilience: concepts and measurements. Oxford Development Studies, 37(3), pp.229-247. 
Caragliu, A., Del Bo, C. and Nijkamp, P., 2011. Smart Cities in Europe. Journal of Urban Technology, 18(2), pp.65-82.

Davoudi, S., Shaw, K., et al., 2012. Resilience: A Bridging Concept or a Dead End? The Politics of Resilience for Planning: A Cautionary Note. Planning Theory \& Practice, 13(2), pp.299-333.

Folke, C., 2006. Resilience: The emergence of a perspective for social-ecological systems analyses. Global Environmental Change, 16(3), pp.253-267.

Garmezy, N., 1991. Resilience in children's adaptation to negative life events and stressed environments. Pediatrics, 20(9), pp.459-466.

Godschalk, D.R., 2003. Urban Hazard Mitigation: Creating Resilient Cities. Natural Hazards Review, [e-journal] 4(3), pp.136 - 143. http://dx.doi.org/10.1061/(ASCE)1527-6988(2003)4:3(136).

Gunderson, L.H. and Holling, C.S. eds., 2002. Panarchy: understanding transformations in human and natural systems. Washington, D.C.: Island Press.

Hamel, G. and Välikangas, L., 2003. The Quest for Resilience. Harvard Business Review, 81(9), pp.52-63.

Hassink, R., 2010. Regional resilience: a promising concept to explain differences in regional economic adaptability?. Cambridge Journal of Regions, Economy and Society, 3(1), pp.45-58.

Hollands, R.G., 2008. Will the real smart city please stand up?. City, 12(3), pp.303-320.

Holling, C.S., 1973. Resilience and Stability of Ecological Systems. Annual Review of Ecology and Systematics, 4, pp.1-23.

Jabareen, Y., 2013. Planning the Resilient City: Concepts and Strategies for Coping with Climate Change and Environmental Risk. Cities, [e-journal] 31, pp. 220 - 229. http://dx.doi.org/10.1016/j.cities.2012.05.004.

Jacobs, J., 1961. The Death and Life of Great American Cities. New York, NY: Random House.

Lagravinese, R., 2015. Economic crisis and rising gaps North-South: evidence from the Italian regions. Cambridge Journal of Regions, Economy and Society, 8(2), pp.331-34.

Lu, P. and Stead, D., 2013. Understanding the notion of resilience in spatial planning: A case study of Rotterdam, The Netherlands. Cities, [e-journal] 35, pp. 200 - 212. http://dx.doi.org/10.1016/j.cities.2013.06.001.

Luthar, S.S., Cicchetti, D. and Becker, B., 2000. The construct of resilience: a critical evaluation and guidelines for future work. Child Development, 71(3), pp.543-562. 
Martin, R., 2012. Regional economic resilience, hysteresis and recessionary shocks. Journal of Economic Geography, 12(1), pp.1-32.

Martin, R. and Sunley, P., 2015. On the notion of regional economic resilience: conceptualization and explanation. Journal of Economic Geography, [e-journal] 15(1), pp.1 - 42. http://dx.doi.org/10.1093/jeg/lbu015.

Meerow, S., Newell, J.P. and Stults, M., 2016. Defining urban resilience: A review. Landscape and Urban Planning, 147, pp.38-49.

Modica, M. and Reggiani, A., 2015. Spatial economic resilience: Overview and perspectives. Networks and Spatial Economics, 15(2), pp.211-233.

Mykhnenko, V., 2016. Resilience: A Right-Wingers' Ploy?, In: S. Springer, K. Birch and J. MacLeavy, eds. 2016. The Handbook of Neoliberalism. New York and London: Routledge. pp.190-206.

Newman, P., Beatley, T., et al., 2009. Resilient Cities. Responding to Peak Oil and Climate Change. Washington, D.C.: Island Press.

Norris, F., Stevens, S., Pfefferbaum, B., Wyche, K. and Pfefferbaum, R., 2008. Community Resilience as a Metaphor, Theory, Set of Capacities, and Strategy for Disaster Readiness. American Journal of Community Psychology, 41(1-2), pp.127-150.

Olsson, P., Galaz, V. and Boonstra, W.J., 2014. Sustainability transformations: A resilience perspective. Ecology and Society, [e-journal] 19(4, Art.1), 13p. http://dx.doi.org/10.5751/ES-06799-190401.

Olsson, L., Jerneck, A., Thoren, H., Persson, J. and O’Byrne, D., 2015. Why Resilience is Unappealing to Social Science: Theoretical and Empirical Investigations of the Scientific Use of Resilience. Science Advances, 1(4), pp.111.

Papa, R., Galderisi, A., Vigo Majello, M.C. and Saretta, E., 2015. Smart and resilient cities. A systemic approach for developing cross-sectoral strategies in the face of climate change. Tema. Journal of Land Use, Mobility and Environment, [e-journal] 8(1), pp. 19 - 49. http://dx.doi.org/10.6092/19709870/2883.

Pelling, M., 2011. Adaptation to Climate Change. From Resilience to Transformation. London: Routledge.

Pendall, R., Foster, K.A., et al., 2010. Resilience and regions: building understanding of the metaphor. Cambridge Journal of Regions, Economy and Society, 3(1), pp.59-70.

Perrings, C., 1998. Resilience in the dynamics of economy-environment systems. Environmental and Resource Economics, 11(3-4), pp.503-520. 
Pickett, S., Cadenasso, M. and Grove, J., 2004. Resilient Cities: Meaning, Models, and Metaphor for Integrating the Ecological, Socio-Economic, and Planning Realms. Landscape and Urban Planning, 69(4), pp.369-384.

Pimm, S.L., 1984. The Balance of Nature. Chicago: University of Chicago Press.

Reggiani, A. and Nijkamp, P., 2009. Simplicity in Complex Spatial Systems. In: A. Reggiani and P. Nijkamp, eds. 2009. Complexity and Spatial Networks, Advances in Spatial Science. Dortrechtt, Heidelberg, London, New York: Springer. Chapter 1. http://dx.doi.org/10.1007/978-3-642-01554-0_1.

Rogers, C.D.F., Quinn, A.D. et al., 2012. Resistance and resilience - paradigms for critical local infrastructure. Proceedings of the ICE - Municipal Engineer, [ejournal] 165(2), pp.73-83. http://dx.doi.org/10.1680/muen.11.00030.

Simmie, J. and Martin, R., 2010. The Economic Resilience of Regions: Towards an Evolutionary Approach. Cambridge Journal of Regions, Economy and Society, 3(1), pp.27-43.

Stumpp, E.M., 2013. New in town? On resilience and resilient cities. Cities, [ejournal] 32, pp. 164 - 166. http://dx.doi.org/10.1016/j.cities.2013.01.003.

Walker, B. and Salt, D., 2006. Resilience thinking: Sustaining ecosystems and people in a changing world. Washington, D.C.: Island Press.

Wamsler, C., Brink, E. and Rivera, C., 2013. Planning for climate change in urban areas: From theory to practice. Journal of Cleaner Production, [e-journal] 50, pp. 68 - 81. http://dx.doi.org/10.1016/j.jclepro.2012.12.008.

\section{ABOUT THE AUTHOR}

Oto Hudec is a professor at the Department of Regional Science and Management, Faculty of Economics, Technical University of Kosice, e-mail: oto.hudec@tuke.sk.

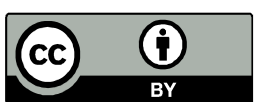

(C) 2017 by the authors. Submitted for possible open access publication under the terms and conditions of the Creative Commons Attribution (CC-BY) license (http://creativecommons.org/licenses/by/4.0/). 